\title{
Christian X og Sønderjylland
}

\author{
Af KNUD J.V. JESPERSEN
}

Ved Genforeningen 1920 blev Sønderjylland atter en del af det danske monarki efter 56 års adskillelse. Ved samme lejlighed skiftede Christian X position fra $i$ befolkningens ejne at være en politiserende monark til at blive et nationalt samlingsmærke hævet over politiske stridigheder - en status, han bevarede $i$ resten af sin lange regeringstid. Med udgangspunkt $i$ kongens egne optegnelser viser historikeren Knud J.V. Jespersen, hvilken central rolle det sønderjyske spørgsmål spillede for kongens handlemåde under Påskekrisen i marts 1920 og $\mathrm{i}$ forbindelse med Genforeningen få måneder senere. Artiklen er baseret på kildemateriale, som forfatteren har fremlagt $\mathrm{i}$ to tidligere bøger om emnet, nemlig Rytterkongen. Et portræt af Christian 10. (2007) og Vejen hjem. Sonderjyske skæbner 1864-1920 (2012).

\section{Kongehuset og Sønderjylland}

Tirsdag den 10. februar 1920 var dagen, hvor befolkningen i 1 . afstemningszone, det vil sige området fra Kongeåen og ned til den nuværende dansk-tyske grænse, skulle afgøre, om den ville blive under tysk styre eller for fremtiden høre til Danmark. Resultatet blev som bekendt et klart ja til forening med Danmark - 75 procent af de stemmeberettigede stemte for dette, mens 25 procent stemte imod. Da resultatet dagen efter forelå, blev der i København afholdt Statsråd under forsæde af Christian X. Kongen fremsatte ved mødets begyndelse følgende erklæring:

»Da min kære bedstefader for omtrent 56 år siden tog afsked med den befolkning, hvis efterkommere snart vender tilbage til Danmark, tolkede han folkets smerte over sønderlemmelsen; men i sit hjerte bevarede han håbet om, at en dag med oprejsning, retfærdighed og lykke en gang ville oprinde. Min fader skulle ikke opleve det, han i tanken omfattede med tro og tillid. Det er uforskyldt faldet i min lod at se denne store dag. I dyb taknemmelighed til Gud, i erindring om levende og døde, der har kæmpet for at bevare danskheden i Slesvig og i håb om en lykkelig fremtid sender jeg - her foran Statsrådet den første velkomsthilsen til de tilbagevendende landsmænd, hvis 
lange og trange udlændighed forøgede og styrkede deres kærlighed til fædrenes land. Gud bevare Danmark og det danske folk! « ${ }^{1}$

For de tavst lyttende radikale ministre har disse kongeord næppe været andet end højstemte tirader; men der er til gengæld ikke tvivl om, at kongens ord kom lige fra hjertet og udtrykte et dybt personligt engagement $\mathrm{i}$ grænselandets skæbne. Det viser alene hans stærke understregning af, at sønderjydernes skæbne altid havde været både en livs- og æressag for kongeslægten, og den klare betoning af at Sønderjyllands tilbagevenden også i høj grad var en personlig æresoprejsning for kongehuset. Med sit ordvalg udtrykte kongen med andre ord den nære forbindelse, der historisk set altid havde bestået mellem kongehuset og grænselandets befolkning helt tilbage fra hertugdømmet Slesvigs opståen i middelalderen.

Hvis Christian X havde haft magt, som han havde agt, ville hans velkomsthilsen til de tilbagevendende sønderjyder i Statsrådet 11. februar have omfattet større dele af det tidligere hertugdømme Slesvigs befolkning. Det blev imidlertid forhindret ved afstemningen i 2 . zone 14. marts 1920, der faldt ud til gunst for Tyskland. Hans bestræbelser for et samlet Slesvigs tilbagevenden blev desuden systematisk modarbejdet af den radikale regering under statsminister $C$. Th. Zahles ledelse.

Med baggrund i kongens egne skriftlige optegnelser vil der i det følgende blive argumenteret for, at Christian X i lighed med bedstefaderen i hjertet var helstatsmand, og at han lige fra krigsafslutningen i 1918 og frem til Genforeningen i 1920 energisk forfulgte det mål at få hele Slesvig tilbage enten som en integreret del af kongeriget eller nært knyttet til dette med kongehuset som forbindende led. Det vil videre blive søgt sandsynliggjort, at denne grundholdning hos kongen var den egentlig udløsende faktor i Påskekrisen 1920, der var nær ved at kaste landet ud i politisk og økonomisk kaos og en kort overgang fik selve kongetronen til at vakle.

\section{Arven fra bedstefaderen}

Holdningsmæssigt og mentalt set var Christian $X \mathrm{i}$ langt højere grad sin bedstefars sønnesøn end $\sin$ fars søn. Selv om han aldrig hverken i skrift eller tale ytrede et eneste nedsættende ord om sin far, var det åbenlyst, at han på ingen måde delte Frederik VIII's liberalistiske anskuelser eller dennes sympati for Systemskiftet i 1901, som introducere- 


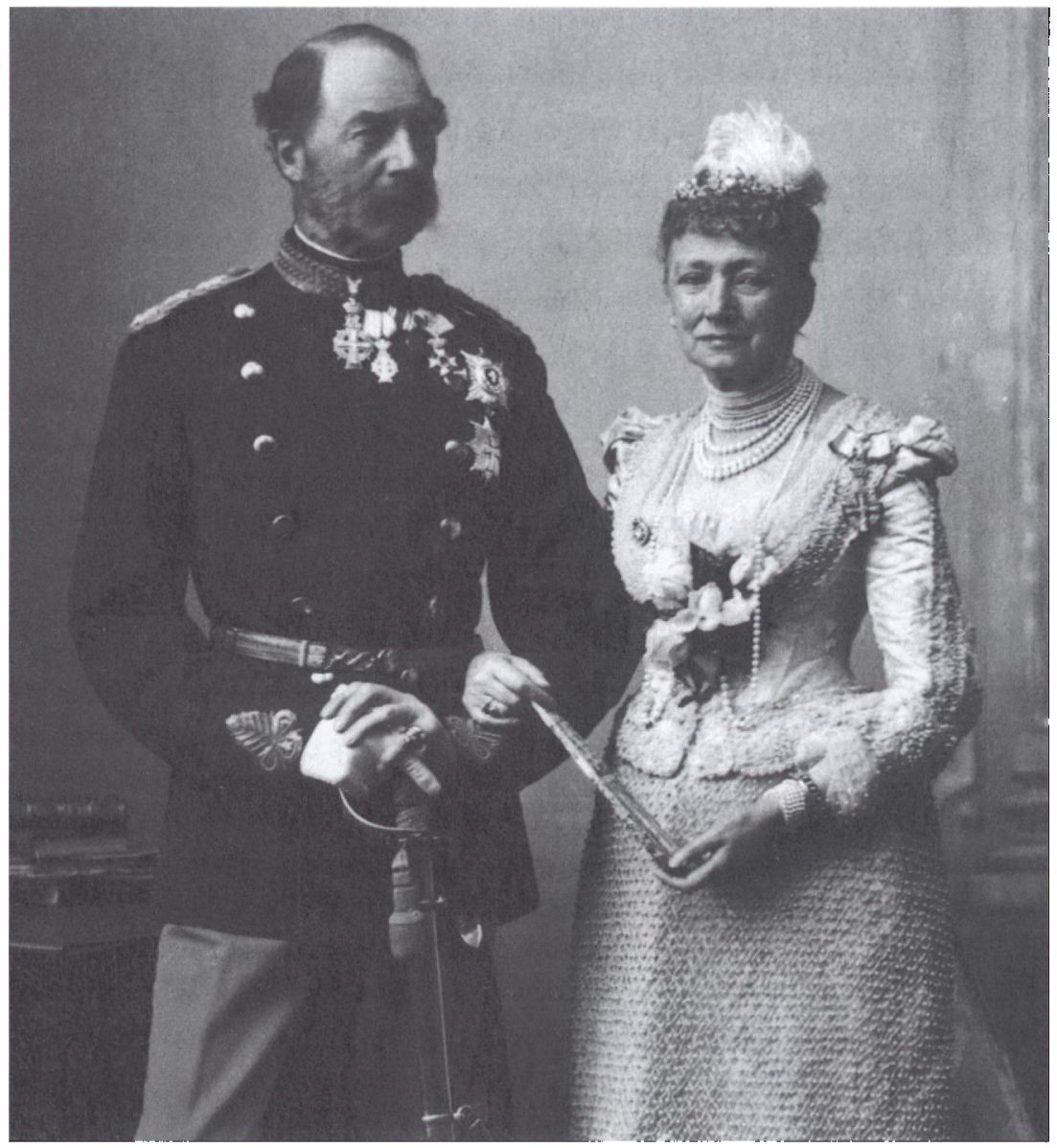

Officielt foto af Christian IX og Dronning Louise $i$ anledning af deres guldbryllup $i$ 1892. Christian IX forblev hele livet tro mod de konservative normer, som han var vokset op med under den sene enevælde. Han blev også $i$ denne henseende et forbillede for sonnesønnen Christian X. Fra Rytterkongen, s. 43.

de parlamentarismen i Danmark. Med sin militære baggrund og soldatermæssige tankegang lå han i adfærd og tankesæt langt nærmere på sin bedstefar, Christian IX, som han gennem hele sin barndom og ungdom havde knyttet sig nært til og nærede stor beundring for.

Den slesvigsk fødte Christian IX kom som ung mand til Frederik VI's enevældige hof, hvor hans forestillinger om kongemagtens centrale politiske rolle i statsstyret blev formet. Ideen om kongens endeli- 
ge ansvar for landets ve og vel og opfattelsen af kongemagten som selvstændig politisk aktør på linje med regering og rigsdag videreførte han i sin egen lange regeringstid fra 1863 til 1906. Hans insisteren på denne rolle - dygtigt sekunderet af den konservative konseilspræsident J.B.S. Estrup - var stærkt medvirkende til de forbitrede forfatningskampe mellem Højre og Venstre, der satte stærkt præg på det politiske liv i de sidste årtier af 1800-tallet, hvor kongen - utvivlsomt ud fra de ædleste motiver - nærmest fremstod som allieret med de konservative kræfter personificeret i Estrup.

Christian IX anskuede fædrelandets vel i en konservativ optik, og der herskede ikke den ringeste tvivl om hans oprigtige kærlighed til fædrelandet som helhed. Som prins kæmpede han således under Treårskrigen aktivt på dansk side som rytterofficer mod den slesvigholstenske løsrivelsesbevægelse. Men som slesvigsk født var hans fædrelandsfølelse ikke begrænset til kongeriget, men omfattede også Slesvig og til dels Holsten, som fra gammel tid havde været en del af den danske konges riger og lande. Han var i sin grundindstilling en helstatsmand, der betragtede den nymodens fremadstormende nationalisme som en fare for den monarkisk definerede verdensorden, som han var vokset op med og satte pris på.

Hans grundlæggende helstatstænkning kom måske klarest til udtryk $\mathrm{i}$ hans handlemåde $\mathrm{i}$ de kritiske dage efter den preussiske erobring af Als 29. juni 1864, der i praksis afsluttede den ulykkelige krig og endeligt beseglede det danske nederlag. ${ }^{3}$ I denne paniske situation, hvor det stod uklart, hvor langt videre preusserne var rede til at gå militært, tog Christian IX - uden at rådføre sig med regeringen det drastiske skridt via den belgiske konge $\mathrm{i}$ fortrolighed at foreslå den preussiske regering, at Danmark som helhed indtrådte som medlem af Det tyske Forbund mod at Hertugdømmerne blev givet tilbage til den danske krone. Dette forslag blev blankt afvist af Bismarck og blev derfor kvalt i fødslen; men det afslører $i$ et glimt to ting om kongen og hans tænkemåde.

For det første, at han mente sig berettiget til at optræede som selvstændig politisk aktør $i$ en sag, som efter hans opfattelse tjente hans lands og folks interesser bedst. Og for det andet, at han ikke tillagde snævre nationalitetshensyn synderlig vægt, men netop tænkte i de helstatsbaner, som var fremherskende $\mathrm{i}$ hans ungdoms enevældige Danmark. En sen eftertid, for hvem nationalstaten nærmest er det givne udgangspunkt, vil måske være tilbøjelig til at dømme kongens 
handlemåde som lodret landsforræderi; men det er en anakronistisk dom at fælde over en tid, hvor nationalstaterne endnu var i deres vorden, og hvor helstatsdannelser som den danske stadig var en del af normalbilledet. Christian IX opfattede sig som retmæssig konge over både sine dansk- og tysktalende undersåtter, og han oplevede det derfor som et personligt tab og en uafvaskelig plet på kongehusets ære, da Hertugdømmerne gik tabt efter en fejlslagen krig, som han fra begyndelsen havde været stærkt imod.

Det var disse grundholdninger, som han videregav til sin sønnesøn, der villigt tog dem til sig og gennem sine mange samtaler med bedstefaderen fik et levende indtryk af, hvor dybt beskæmmet denne - både på egne og på kongeslægtens vegne - var over tabet af Hertugdømmerne. På denne måde var Christian $X$ lige fra barnsben blevet indpodet, at Hertugdømmerne - og især Slesvig - havde en ganske særlig plads i kongeslægtens selvforståelse og historie, og at det knæk, som slægtens ære havde lidt ved tabet af dem, kun kunne genoprettes ved at vinde $i$ det mindste noget af det tabte tilbage. Det er på den baggrund ikke spor overraskende, at ordet ære kom til at udgøre en del af den treenighed, som siden blev Christian X's officielle valgsprog: »Min Gud, mit Land, min Ære«. Deri lå nærmest en programerklæring og en grundfæstet livsholdning, som skulle blive afgørende for kongens handlinger og optræden, da en generhvervelse af noget af det tabte viste sig som en mulighed efter Tysklands sammenbrud i 1918.

\section{Christian X og ministeriet Zahle 1918-19}

1918 blev det år, hvor den store krig med alle dens lidelser og ødelæggelser omsider fik ende, og Tysklands sammenbrud blev en kendsgerning. Denne udgang tændte for alvor håbet hos mange danske om - med de vestallierede sejrsmagters hjælp - at vinde en del af det tabte land tilbage. Det gjaldt naturligvis også Christian X. Ved årets udgang sammenfattede han i sin private dagbog sine håb og ønsker med følgende bemærkning:

»Med tak til Gud sluttes 1918 for al hans usigelige nåde mod os alle for at have holdt sin skærmende hånd over Danmark i disse tunge år, siden august 1914 for hele verden, og med tak for den signede dag vi synes er ved at oprinde, hvor det skilte atter skal samles, og hvor 


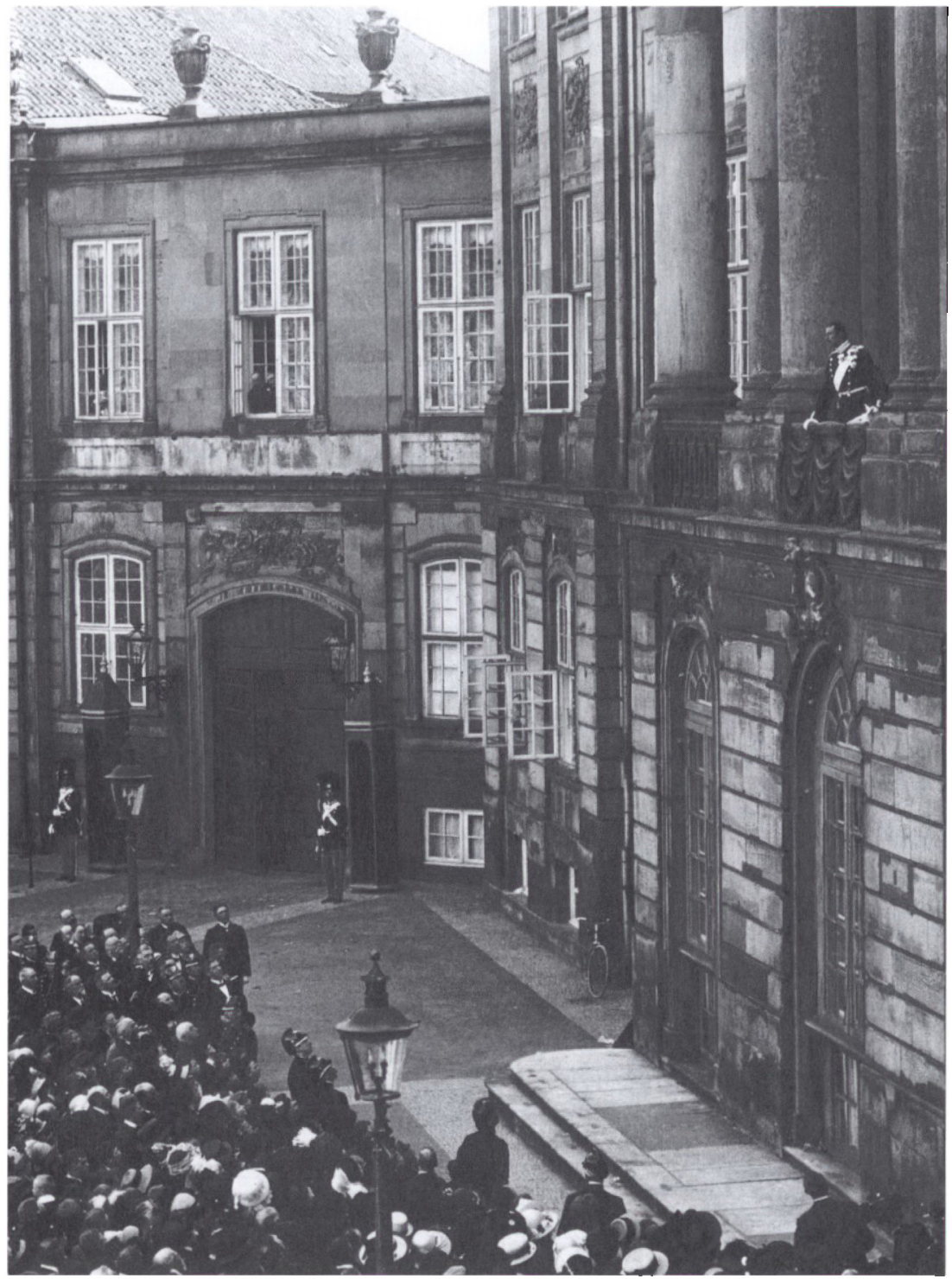

Christian X modtager folkets hyldest på Amalienborg Slotsplads den 15. maj 1912, da han blev udråbt til konge. Som sit valgsprog tog han "Min Gud, mit Land, min Ære" - en programerklæring, der også blev bestemmende for hans ageren $i$ genforeningssagen. Fra Rytterkongen, s. 136. 
Slesvig atter forenes med os efter hans vilje. Han lader os i ydmyghed og med tak modtage dem, når genforeningens time slår. « ${ }^{4}$

Det er værd at lægge mærke til, at kongen her ikke talte om Sønderjylland eller dele af Slesvig, men slet og ret om »Slesvig", hvormed han åbenlyst mente hele det gamle hertugdømme.

Dermed gjorde kongen det klart, at det samlede Slesvigs tilbagevenden til den danske krone som udgangspunkt var hans ønske og håb på samme måde, som det havde været hans fars og bedstefars ønskemål. Og det løb som en rød tråd gennem alle hans ytringer og dagbogsnotater lige fra våbenstilstanden og frem til Påskekrisen $i$ 1920, at dette var hans højeste prioritet og den egentlige bevæggrund for de fleste af hans handlinger.

Men dermed var han fra første færd på direkte kollisionskurs med den radikale Zahle-regering og især udenrigsminister Erik Scavenius, hvis lige så klare standpunkt var, at en eventuel grænserevision kun skulle omfatte den nordlige, overvejende dansksindede del af det tidligere hertugdømme, det vil sige området ned til den nuværende grænse. Rationalet bag regeringens holdning var, at det på længere sigt kunne være farligt at provokere et måske kun midlertidigt svækket Tyskland ved at stille for omfattende krav, og at for mange tysksindede nord for den nye grænse kun ville give anledning til uro. Omvendt anskuede kongen først og fremmest sagen under en slægtsmæssig synsvinkel, og ifølge den var Slesvig en udelelig helhed under den danske krone. Der var kort sagt tale om uforenelige holdninger udsprunget af vidt forskellige måder at anskue slesvigproblematikken på.

Det kom til at stå lysende klart i de samtaler, som kongen førte med Scavenius i tiden omkring våbenstilstandsaftalen. I en samtale 18. oktober 1918, hvor de to drøftede Tysklands nært forestående sammenbrud og det deraf følgende genforeningsspørgsmål, gjorde kongen det klart, at han af slægtsmæssige grunde ønskede hele Slesvig genforenet med Danmark. Samtidig understregede han dog, at der var tale om et personligt ønske, som naturligvis måtte underordnes regering, rigsdag og folk. Hertil replicerede Scavenius afmålt, at han ikke alene fandt kongens ønske urealistisk, men også direkte skadeligt for de videre forhandlinger. ${ }^{5}$

Diskussionen mellem de to blev genoptaget under udenrigsministerens foretræde 14 dage senere, 6. november 1918, hvor bølgerne efter kongens referat at dømme synes at være gået højt. Kongen ind- 
ledte med at bebrejde Scavenius, at denne kørte sit eget løb i genforeningsspørgsmålet uden at holde ham orienteret, hvilket han havde erfaret under en samtale to dage forinden med Ø.K.'s direktør H.N. Andersen. Kongen understregede i forlængelse deraf, at han af hensyn til regeringen hidtil havde tilsidesat sine egne følelser i denne sag, men pegede i øvrigt på, at når islændingene netop havde kunnet vælge deres egen konge, så »kan vi ikke hindre, at f.eks. slesvigerne vælger mig, der har et berettiget arvekrav « ${ }^{6}$

Hvad kongen her mere end antydede som en mulig udvej, var med andre ord en slags helstatsløsning, hvorved hele Slesvig igen knyttedes til Danmark gennem en fælles konge. Det vidner om, i hvor høj grad Christian $X$ havde overtaget bedstefaderens arvegods. Denne havde, som tidligere nævnt, også i sin tid haft følere ude for at opnå en lignende losning. Disse forestillinger bragte tilsyneladende Scavenius helt op i det rode felt. Stærkt ophidset erklærede han, at det netop var det farlige ved kongen, at han førte politik med hjertet og ikke med hjernen, og han fastslog som sit og regeringens standpunkt, at »vi ikke har brug for tyskere inden for vort territorium.«

Dermed var fronterne trukket skarpt op - måske også for skarpt. Fire dage senere gik Scavenius nemlig bodsgang til Sorgenfri for over for kongen at undskylde sin noget ubeherskede optræden forleden. Kongen modtog undskyldningen, men fastholdt i øvrigt sin opfattelse. Dette kom klart til udtryk i en fortrolig samtale, som han 14. maj 1919 havde med finansminister Edvard Brandes, det eneste medlem af regeringen, som han havde et tillidsfuldt forhold til. ${ }^{7}$ Uden omsvøb erklærede kongen under den lange samtale, at han fandt Scavenius alt for egenrådig og ensidigt tyskvenlig i sin grænsepolitik, og han tilføjede ifølge sit eget referat: "Jeg førte ikke - og agtede ikke at føre - en personlig politik uden om Rigsdagen, men erkendte, at mine følelser hvilede på den historiske Dannevirkegrænse - idet Slesvig efter min opfattelse strakte sig så langt.«

Han fandt, at eventuelle problemer med det tyske befolkningselement $i$ et genforenet Slesvig let ville kunne løses, idet han var overbevist om, at også de tyske slesvigere ville være loyale over for ham. Brandes, hvis indflydelse i regeringen på dette tidspunkt $\mathrm{i}$ øvrigt var stærkt på retur, udtrykte ganske vist forståelse for kongens holdning, men erklærede sig dog uenig i dennes optimistiske syn på problemerne $\mathrm{i}$ forbindelse med indlemmelse af et udelt Slesvig.

30. juni 1919 blev der afholdt statsråd i anledning af den endelige 


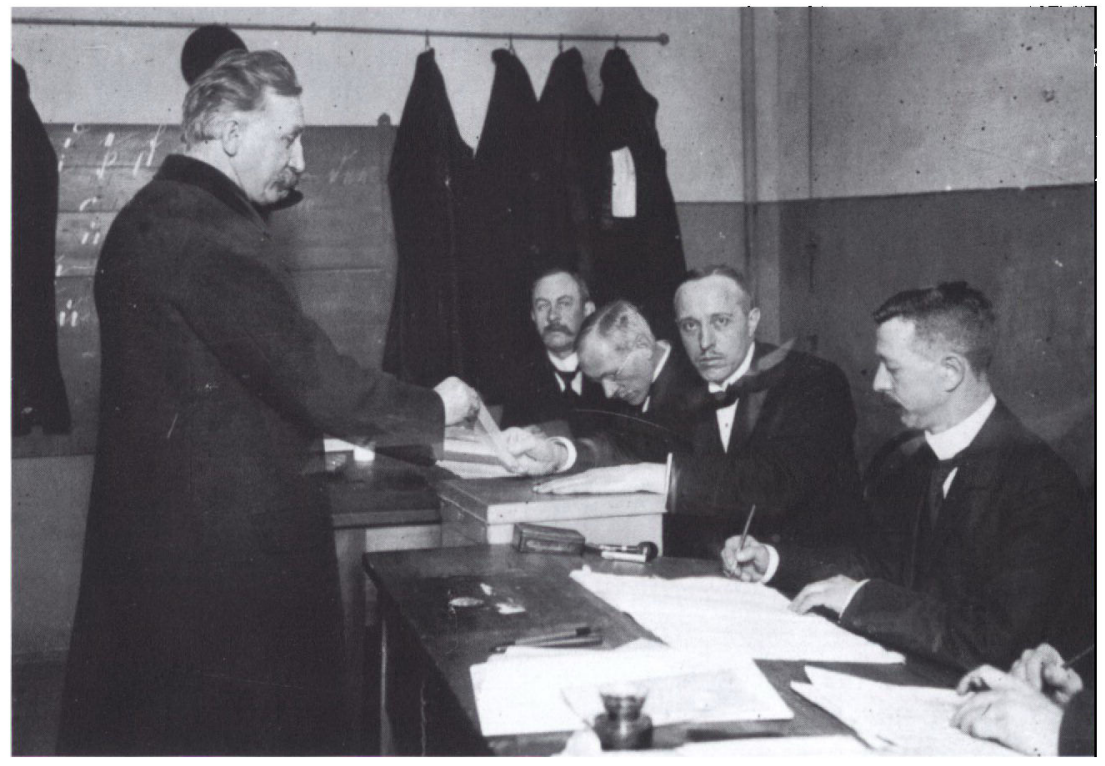

Det danske mindretals leder, redakter H.P. Hanssen, afgiver sin stemme ved et valg, mens Sonderjylland endnu var under tysk styre. H.P. Hanssen (1862-1936) var redaktor af Aabenraa-avisen Hejmdal. I direne 1906-19 repræsenterede han mindretallet $i$ den tyske rigsdag, og 1919-20 varetog han som minister for sønderjyske anliggender $i$ den radikale Zahle-regering landsdelens interesser $i$ afstemningsperioden. Fra Vejen hjem, s. 52.

fredsslutning mellem de stridende stormagter og den sønderjyske leder, redaktør H.P. Hanssens indtræden i Zahle-regeringen som særlig ansvarlig for sønderjyske anliggender. Kongen benyttede denne anledning til at gøre sin holdning helt klar over for den samlede regering. I en udtalelse ved mødets begyndelse fastslog han: ${ }^{8}$

"Jeg kan ikke ved denne lejlighed undlade at mindes min højtelskede bedstefader, hvis vugge stod i Slesvig - et forhold, der bevirkede, at han i begyndelsen af sin regeringstid herhjemme stempledes som tysker - og som aldrig glemte sine landsmænd. Ligesom jeg også mindes min højtelskede fader, der havde været mere berettiget til at opleve denne tid end jeg, som så ufortjent i min korte regeringstid skal opleve denne lykke.«

Tydeligere kunne det vist ikke siges, at kongens opfattelse var uændret, at Slesvigs tilbagevenden til Danmark for ham var et dybt personligt og slægtsbestemt anliggende, og at Slesvig for ham var hele 
Slesvig. De lyttende ministre kunne efter dette ikke være i tvivl om, at de fra kongens side ville få kamp til stregen i grænsedragningsspørgsmålet. Det kom også til at holde stik.

\section{Fronterne trækkes op 1919-20}

Da debatten om grænsesagen for alvor tog fart fra efteråret 1919, blev synspunkterne $\mathrm{i}$ den offentlige debat efterhånden trukket op med større og større skarphed. Regeringens tilhængere forsvarede stædigt en grænsedragning efter sindelagsprincippet, hvorimod mere konservative kredse med stigende styrke agiterede for en sydligere grænse. Også på de indre linjer, i forholdet mellem kongen og regeringen, skærpedes fronterne. Utvivlsomt opmuntret af den tiltagende offentlige kritik af regeringens tilbageholdende linje i grænsesagen, gik også kongen i højere grad i offensiven over for ministeriet, som han mere og mere betragtede som den væsentligste modspiller i det, der for ham forblev en hjertesag.

Det skærpede modsætningsforhold kom klart til udtryk i en fortrolig samtale, som Christian X 27. oktober 1919 havde med Berlingske Tidendes redaktionschef, Svenn Poulsen. I løbet af samtalen, der førtes under tavshedsløfte, kom kongen også ind på grænsesagen og betroede ifølge sit eget referat Poulsen følgende: ${ }^{9}$ "Jeg troede ikke, regeringen nåede at komme derned som ministerium, thi jeg mente, at kun rene hænder kom til at modtage Slesvig, og rene kaldte jeg dem, der trofast havde talt for dem dernede.«

Disse åbenhjertige kongeord kan meget vel tolkes som et forvarsel om det drama, der kom til at udspille sig fem måneder senere, da kongen $\mathbf{i}$ forbindelse med Påskekrisen afskedigede ministeriet Zahle. Og de vidner under alle omstændigheder om den afgrundsdybe mistillid mellem kongen og ministeriet $\mathrm{i}$ grænsedragningsspørgsmålet. Selv om Svenn Poulsen i kraft af sit nære slægtskab med flere fremtrædende kongelige skuespillere hørte til i periferien af kongens personlige omgangskreds, vidner alligevel det forbløffende faktum, at Christian $X$ valgte at betro sig til en udenforstående journalist, stærkt om den frustration, der efterhånden havde grebet ham ved at være vidne til regeringens $i$ hans øjne landsskadelige virksomhed. Der var efter hans opfattelse tale om en regering med urene hænder i det slesvigske spørgsmål, en regering, som uden følelse for hverken fædreland eller slesvigernes sag blokerede for det, han mest af alt ønske- 
de, nemlig en forening af Danmark og det Slesvig, der i kongens optik var en udelelig helhed.

Denne kongelige grundholdning kom klart til udtryk, da Scavenius 11. januar 1920 atter var hos kongen for at få godkendt ordlyden af de telegrammer, der skulle sendes til stormagterne $i$ anledning af de endelige ratifikationer af fredsaftalen dagen forinden. ${ }^{10} \mathrm{I}$ telegramteksten indgik en omtale af det landområde, som Danmark håbede ville vende tilbage til landet. Dette havde regeringen i telegramudkastet forsigtigt beskrevet som området "Sønden Kongeå «. Men dette ubestemte udtryk rettede kongen kort og godt til "Slesvig" med en bemærkning om, at: "man burde betragte Slesvig som en helhed, som man ikke vilkårligt kan skære over; selv om sproget er forskelligt, hører befolkningen til samme landsdel.«

Da udenrigsministeren fremhævede farerne ved at optage et for stort tysk befolkningselement, bed Christian $\mathrm{X}$ ham af med en erklæring om: "at jeg selv er part $i$ sagen, derfor så jeg anderledes på det end han; mine følelser for slesvigerne har jeg arvet fra min bedstefader og fader, aldrig har jeg hørt om en deling kun et helt Slesvig.«

Med disse bemærkninger vedkendte kongen sig, at hans holdning til det slesvigske spørgsmål hang uløseligt sammen med hans stærke slægtsfølelse, og han plæderede lige ud for en slags helstatsløsning, der kunne minde om situationen før 1864. Dermed trådte han åbent op imod den løsning efter nationalitetsprincippet, som regeringen ønskede.

Den uforsonlige stemning mellem de to parter mildnedes ingenlunde af afstemningen i 1. zone 10. februar 1920, der gav et klart flertal for Danmark. Tværtimod skærpede resultatet snarere skyttegravskrigen mellem kongen og ministeriet. Det gunstige udfald fik nemlig Christian $X$ til at vejre ny morgenluft for sit ønske om at få $i$ det mindste også 2. zone tilbage, mens det omvendt bekræftede ministeriet i rigtigheden af den kurs, som det hidtil havde fulgt. Det blev klart på et stormfuldt møde 10. marts 1920 - fire dage før afstemningen i 2. zone skulle finde sted - mellem kongen og regeringstoppen repræsenteret ved statsminister Zahle og udenrigsminister Scavenius. ${ }^{11}$

Baggrunden for mødet var, at der søndagen forinden, den 7. marts, havde været et stort folketog til Amalienborg til støtte for kravet om Flensborgs genforening med Danmark uanset afstemningsresultatet $\mathrm{i}$ 
2. zone. Under demonstrationen havde kongen fra residenspalæets balkon offentligt udtalt, at han udmærket forstod de demonstrerendes følelser, hvilket tydeligt mishagede ministrene. På mødet krævede de derfor Amalienborg Slotsplads afspærret for at hindre flere demonstrationer, der efter deres opfattelse kunne forværre landets fremtidige forhold til Tyskland.

Kongen afviste imidlertid kategorisk at gå med til en afspærring af slotspladsen og tilføjede ifølge sit eget referat, "at jeg fra begyndelsen havde sagt, at vi løste opgaven helt forkert - nu var Sønderjylland delt i zoner og kvadrater - et helt roderi!« Han pegede i stedet på muligheden for med den internationale afstemningskommissions bistand at gøre krav på også 2. zones forening med Danmark og føjede derefter til:

"For at fremstille mit personlige forhold måtte jeg bemærke, at disse tysktalende - hvis de kommer til os - i det mindste skal føle, at jeg ikke har slået hånden af dem. Jeg er ingen præsident, der kan takke af - jeg må handle på langt sigt - og ønsker intet hellere end at vide, hvorledes mit folk stiller sig; men mine krav om valg afvises stadig i ministeriet.«

Dette skarpe kongelige angreb på regeringen og dens politik bragte Zahle til lige så skarpt at bemærke, at kongen i den nuværende situation var den eneste, der kunne berolige gemytterne, hvorfor det var vigtigt, at han ikke tog for stærkt parti. I så fald, mente Zahle, kunne han "risikere tog mod Flensborg på mange tusinder - og så var det hele kaos. « Dertil replicerede kongen, at han da gerne modtog sådanne tog, og at skylden for forvirringen lå hos Zahle selv. Efter kongens opfattelse var demonstrationerne både for Flensborg og mod regeringen, hvorfor et valg efter hans mening var den eneste løsning.

$\mathrm{Nu}$ var Zahle for alvor bragt $\mathrm{i}$ harnisk. Han påpegede vredt, at regeringens demission ville bringe kongen i en yderst pinlig situation, idet regeringen hvilede på et parlamentarisk flertal, og Rigsdagen var det forum, hvori den skulle stå til regnskab - ikke over for en hob "sammenløbne demonstranter«. Selvsikkert føjede Zahle til, at hans støttepartier ønskede, at han skulle modtage Genforeningen, og derfor blev han, "ligesom han var sikker på at komme tilbage med en knusende majoritet."

Denne uhørt skarpe ordveksling, hvor begge parter gav råt for usødet, mindede mest af alt om et åbent brud mellem kongen og ministeriet på grænsedragningsspørgsmålet. På den ene side stod Chri- 


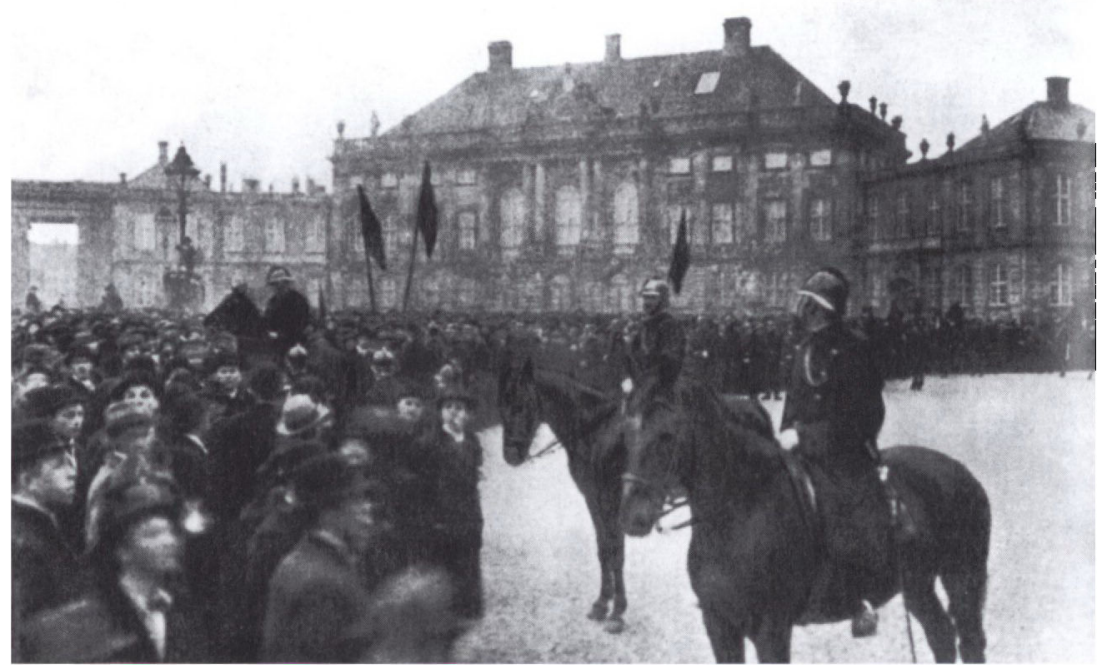

Folkelig demonstration på Amalienborg Slotsplads $i$ de kritiske dage under Påskekrisen omkring 1. april 1920. Om ikke for erfarede Christian X ved denne lejlighed hvilken hoj pris, der kunne være forbundet med at være politiserende monark. Fra Rytterkongen, s. 312.

stian X, der - som det vil være fremgået af gennemgangen af hans ytringer helt tilbage til 1918 - af hele sit hjerte ønskede hele Slesvig tilbage, om fornødent som led i en slags helstatsløsning, for på den måde at indfri den gæld, som han mente at stå i til sine forgængere på tronen. For ham var sagen personlig og slægtsbestemt, og under hans synsvinkel repræsenterede et betydeligt tysktalende befolkningselement ikke noget større problem, ligesom forholdet til det slagne Tyskland ikke for ham spillede nogen særlig rolle. På den anden stod den radikale regering. For den var hensynet til Tyskland en hovedsag og en videreførelse af krigsårenes neutralitetskurs med tysk hældning fortsat vigtig for Danmarks sikkerhed. Derfor modsatte den sig med næb og kløer en grænsedragning, der implicerede et stort tysk befolkningselement nord for den dansk-tyske grænse. Det kunne efter deres opfattelse blive yderst farligt, når Tyskland engang atter rejste sig af asken.

Begge standpunkter var hver især ud fra deres respektive forudsætninger fuldt forståelige, men til gengæld fuldstændig uforenelige. Kursen var dermed lagt frem mod kongens afskedigelse af ministeriet 19 dage senere i et sidste fortvivlet forsøg på at påvirke den interna- 
tionale afstemningskommissions afgørelse til gunst for en sydligere grænsedragning end 1. zone. Der kan efter det foreliggende ikke herske større tvivl om, at slesvigspørgsmålet var et hovedmotiv for kongens drastiske handling 29. marts 1920. Når hans bestræbelser alligevel endte uden resultat, skyldtes det dels den overbevisende tyske sejr ved afstemningen i 2 . zone 14. marts, dels det kaotiske politiske forløb, der fulgte $\mathbf{i}$ dagene efter afskedigelsen af ministeriet Zahle. Disse højspændte begivenheder - kendt under navnet Påskekrisen bragte momentvis tronen til at vakle og belærte på den hårde måde kongen om, hvor snævre grænserne for en konstitutionel kongemagts politiske handlefrihed i et parlamentarisk demokrati egentlig er. Denne side af historien hører imidlertid ikke til i denne sammenhæng. I stedet kan vi vende os til den begivenhed, som med god ret kan kaldes Christian X's »finest hour« - genforeningsdagen 10. juli 1920, og hvad deraf fulgte.

\section{Genforeningen}

I lighed med tidligere år afsluttede Christian $\mathrm{X}$ også sin private dagbog for året 1920 med en tak til Gud og nogle sammenfattende betragtninger over året, der gik:

"Med tak til Gud sluttes 1920, der usletteligt vil være prentet i hjertet gennem Genforeningens solrige strålende dage. Gud ledede, da hans time kom, alt til det bedste, rigere og fyldigere end nogen tanke havde kunnet udtænke. For mig er det blevet uforglemmeligt ved synlige tegn på Hans Nådes gennemgriben. - Gud hjælpe mig til i ydmyghed at erkende min tak og at tjene mit land og folk. « $^{12}$

Den afsluttende bemærkning om ydmyghed i forhold til sit kald var det nærmeste, kongen her kom en refleksion over årets ene store begivenhed, Påskekrisen. Langt mere eksplicit var han i omtalen af årets anden store begivenhed, Genforeningen. Den er i hans beskrivelse badet i sollys og stråleglans - selv om vejrliget i genforeningsdagene vist $i$ virkeligheden var temmelig skiftende og himlen overskyet - og udlægges som udtryk for Guds vidunderlige førelse og nåde. Selv om den ikke blev opfyldelsen af det mål, som han havde kæmpet så hårdt for - foreningen af hele Slesvig med Danmark - var genforeningen med Nordslesvig for ham alligevel en Guds gave og $i$ det mindste en delvis indfrielse af den slægtsmæssige gæld, som han så dybt følte, at han skyldte sine forgængere på tronen. Den taknem- 
melighed over for de højere magter, der lyser ud af kongens ord, er derfor fuldt forståelig.

Endnu mere forståelig bliver kongens taknemmelighed over Genforeningen, når man betænker den voldsomme politiske storm, som han blot få måneder forinden kun med nød og næppe havde overlevet med kronen $\mathrm{i}$ behold. Hans symbolske ridt ind i det genvundne Sønderjylland på genforeningsdagen 10. juli 1920 og hans optræden ved de følgende dages festligheder $\mathrm{i}$ landsdelen gav ham nemlig for første gang mulighed for at lægge rollen som politiserende monark bag sig og i stedet træde i karakter som det nationale samlingsmærke hævet over daglig politisk strid, som han endte med at blive resten af sin regeringstid. Dermed var tavlen visket ren, og han kunne - takket være Genforeningen - så at sige starte på en frisk og redefinere sin kongerolle.

Selve sceneriet omkring kongens grænseridt var ikke alene en nøje tilrettelagt national manifestation, men havde også en mytologisk dimension, der nærmest med et slag loftede kongen bort fra den politiske sfære og ind i de urørlige ikoners verden. Hele ceremonien var koreograferet $\mathrm{i}$ overensstemmelse med Jomfru Fannys spådom om Genforeningen. Jomfru Fannys borgerlige navn var Franziska Enge (1805-81). Hun ernærede sig som syerske i Aabenraa, men havde tillige synske evner, som gjorde hende til en populær skikkelse blandt dansksindede sønderjyder. Kort før sin død forudså hun i et syn Genforeningen:

"[...] Det bliver ikke Christian IX, som kommer herned som dansk konge. Kongen som kommer hertil, er en mand i sin bedste alder, hverken gammel eller ung. Han kommer ridende på en hvid hest. Bønderne vil pynte deres heste med bonderoser, og der vil være sort af mennesker for at tage imod ham, men jeg ser ikke et eneste bekendt ansigt $[. .]$. « $^{13}$

Jomfru Fannys spådom blev hurtigt kendt viden om, og som følge deraf antog de danske sønderjyders drøm om genforening med Danmark tidligt konkret skikkelse af den danske konge ridende over grænsen på en hvid hest. Kongen på den hvide hest levede så stærkt i folkedrømmen, at det nærmest var utænkeligt, at hans indtog $\mathrm{i}$ landsdelen kunne ske på andre måder, da Genforeningen i 1920 blev en realitet. Begivenhederne på genforeningsdagen 10. juli blev derfor nøje iscenesat, så de kunne leve op til drømmene og forventningerne. På denne måde blev kongen i dette øjeblik selve inkarnationen af 


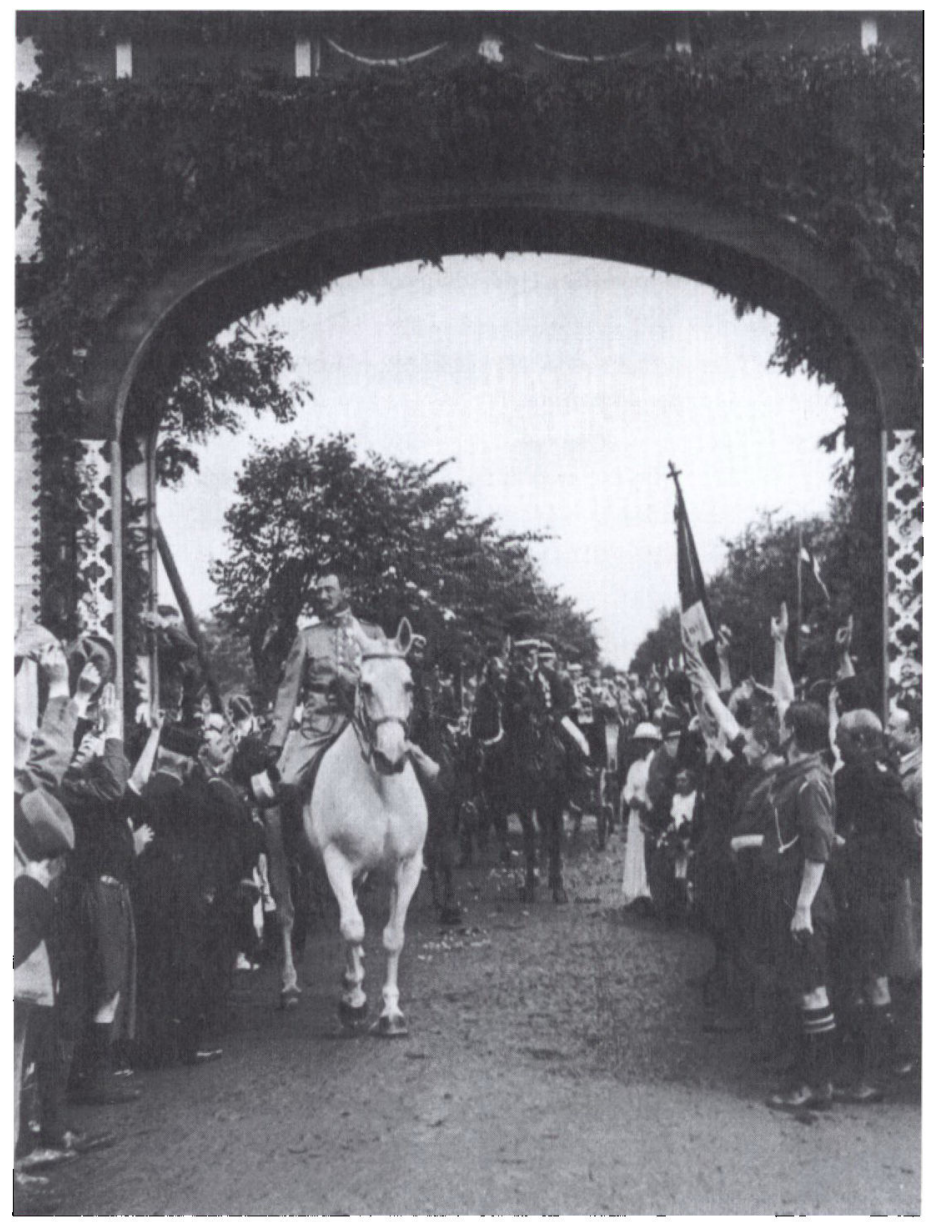

Det bevægende historiske ojeblik, da Christian $X$ i spidsen for den kongelige kortege den 10. juli 1920 red ind i det genvundne Sonderjylland. Fra dette ojeblik var Genforeningen en kendsgerning, og $i$ samme nu skiftede kongen status fra omdiskuteret politiserende monark til nationalt ikon hævet over al partistrid. Fra Rytterkongen, s. 17.

Danmarks og Sønderjyllands skæbne og symbolet på, at i det mindste en del af tabet efter den fejlslagne krig i 1864 nu omsider var udlignet. I kraft af Sønderjylland blev Christian $X$ fra dette øjeblik et urørligt nationalt symbol, hvis navn for stedse er uløseligt knyttet sammen med Sønderjyllands tilbagevenden til Danmark i 1920. Den stærkt troende konge var selv i sit inderste overbevist om, at det hele var 
Guds værk, og at han selv i dette anliggende blot var Guds udvalgte redskab. Det fremgår af de par dagbogslinjer, hvormed han afsluttede sin private beskrivelse af genforeningsdagene: "Gud ske lov for sin Nåde mod os alle, som vi i ydmyghed modtager. Lykkelige os, der oplevede en sådan dag, som slægten håbede på før os. «14

Tydeligere kunne kongens forbundenhed med sin Gud og identifikation med sin slægt og sit folk næppe udtrykkes.

Kongens grænseridt var kulminationen på et forløb, der havde strakt sig hen over foråret 1920, efter at afstemningerne havde afgjort, hvor den nye grænse mellem Danmark og Tyskland skulle drages, og forløbet af Påskekrisen tillige havde gjort det klart, at grænsen mellem 1. og 2. zone skulle være den nye nationalitetsgrænse. 5. maj rykkede danske tropper ind i Sønderjylland, og efter at der var etableret en effektiv spærring af grænsen mellem 1. og 2. zone $70 \mathrm{~km}$ syd for den gamle Kongeågrænse, blev den danske kronemønt indført som gældende betalingsmiddel 20. maj. Samme dag gik administrationen af landsdelens postvæsen over på danske hænder. Natten mellem 26. og 27. maj blev der indført pastvang med tilhørende paskontrol ved den nye grænse, hvilket var et særdeles konkret udtryk for, at det gamle hertugdømme Slesvig nu endegyldigt var delt i et dansk Sønderjylland og et tysk Mellem- og Sydslesvig. 16. juni udløb den internationale kontrolkommissions mandat i området, og 5. juli stadfæstedes overdragelsen af Sønderjylland til Danmark ved en tosidet traktat mellem den danske regering og de allierede sejrsmagter. Fire dage senere, den 9. juli, underskrev Christian $X$ i statsrådet loven om indlemmelse af de sønderjyske landsdele. Det var slutpunktet på den formelle genforeningsprocedure, hvilket de følgende dage blev festligt markeret med kongens grænseridt og genforeningsfester overalt i landsdelen. Den største fest fandt sted 11. juli på Dybbøl - den lokalitet, der i 1864 havde været skueplads for krigens blodigste kampe hvor kongefamilien og regeringen sammen med omkring 100.000 andre deltagere fejrede den historiske begivenhed. ${ }^{15}$

Genforeningen var for sønderjyderne slutpunktet på en 56 år lang og sej kamp, som havde kostet mange ofre både menneskeligt og materielt. Ikke mindst under den seneste storkrig, hvor omkring 30.000 unge mænd fra landsdelen som soldater måtte kæmpe ved krigens fronter under tysk flag. Af disse mistede ikke færre end 5.270 livet under kampene på krigens forskellige fronter, flest i skyttegravskrigen på Vestfronten. De efterlod sig omkring 1.500 unge enker og 
5.000 faderløse børn. Omkring 7.000 vendte hjem som krigsinvalider, mens ca. 4.000 måtte tilbringe kortere eller længere tid i krigsfangelejre i Rusland, Frankrig og England. ${ }^{16}$ Også civilsamfundet led stærkt under krigens tryk, der tærede stærkt på livsmodet og sled infrastrukturen i bund. Det var derfor en hårdt prøvet befolkning og en nedslidt landsdel, der i 1920 vendte tilbage til Danmark.

Selv om kongeriget Danmark i de fleste henseender var sluppet nådigere gennem adskillelsesperioden og i kraft af neutralitetspolitikken kun indirekte havde mærket krigens følger, var Genforeningen økonomisk set en stor mundfuld. Helt konkret kostede genopretningen af Sønderjyllands nedslidte infrastruktur og opbygningen af en dansk forvaltning den danske stat $\mathrm{i}$ omegnen af $300 \mathrm{mio}$. kr. regnet $\mathrm{i}$ 1920-priser. Det var et meget betydeligt beløb, når man tager i betragtning, at dette års samlede finanslov lød på 286,5 mio. kr.

En medvirkende årsag til beløbets størrelse var, at den nye grænsedragning skar en region, der hidtil havde fungeret som en administrativ helhed, midt over, hvilket i forvaltningsmæssig henseende efterlod landsdelen nærmest på bar bund. Og samtidig lå regionens største by, Flensborg, nu syd for grænsen. Mange institutioner og forvaltningsstrukturer skulle derfor nærmest opbygges fra grunden. Den danske stat fremskaffede det store beløb ved at optage et såkaldt "genforeningslån« på 145 mio. kr. og besluttede samtidig at anvende provenuet fra salget af De Vestindiske Øer til USA i 1917 til genforeningsformål. Dette udgjorde i tidens priser omkring 153 mio. kr. Uanset disse kunstgreb repræsenterede Genforeningen en meget betydelig belastning af de danske statsfinanser gennem de første år, hvilket dog på ingen måde dæmpede glæden over begivenheden, der først og fremmest opfattedes som en retfærdighedshandling over for landsdelens danske indbyggere og en delvis oprejsning efter ydmygelsen i 1864 .

\section{Ordensvæsenet og sønderjyderne}

Christian $\mathrm{X}$ var som foran beskrevet en stærkt engageret aktør i spillet om Slesvig og Sønderjylland i tiden mellem 1. Verdenskrigs afslutning og selve Genforeningen, hvori han ligeledes med stort personligt engagement spillede en hovedrolle. Også i tiden derefter - da dagligdagen meldte sig, og den langvarige normaliseringsproces gik i gang - gjorde han, hvad der stod i hans magt for at støtte den gen- 
vundne landsdels integration i det samlede kongerige. Belært af erfaringerne fra Påskekrisen undgik han dog nu omhyggeligt at blande sig direkte politisk. I stedet valgte han at udnytte sin nyerhvervede status som nationalt samlingsmærke i sagens tjeneste. Dette skete ved hyppige rejser rundt i Sønderjylland og ikke mindst ved bevidst anvendelse af det kongelige ordensvæsen, som rummede en betydelig national symbolværdi, og som han fortsat rådede suverænt over. ${ }^{17}$

Både $\mathrm{i}$ forbindelse med selve Genforeningen og $\mathrm{i}$ årene derefter lod han således talrige sønderjyder dekorere med forskellige grader af dannebrogordenen som udtryk for sin og det officielle Danmarks anerkendelse af deres indsats for den danske sag. Ordenstildelingerne gik til en bred skare af de mænd, som i den tyske tid havde stillet sig i spidsen for kampen for danskheden eller på anden vis havde øvet en fortjenstfuld indsats $i$ landsdelen. Det gjaldt sønderjyske politikere, bladfolk, præster, lærere, gårdejere osv., som hver på deres måde havde bidraget til danskhedens overlevelse. Der var tale om hundredvis af dekorationer til disse særlige målgrupper, som til gengæld kvitterede for udmærkelsen med øget kongetroskab og dermed også øget loyalitet over for den danske stat. Skønt en anelse uhåndgribelig skal man ikke undervurdere den integrerende virkning af disse omfattende ordenstildelinger, der gav ordensmodtagerne en fornemmelse af at høre til og være anerkendt af selve nationens inkarnation, kongen.

Der var imidlertid også et andet regnskab på det dekorationsmæssige område, som $\mathbf{i}$ høj grad trængte til at blive gjort op, nemlig den sparsomme dekorering af de tilbageværende veteraner fra krigen i 1864 som officiel anerkendelse af udvist tapperhed. Under og efter 1. Slesvigske Krig 1848-50, der med lidt af en tilsnigelse udlagdes som en entydig sejr for de danske våben, uddeltes der $\mathrm{i}$ alt omkring 2.000 dekorationer $\mathbf{i}$ form af ridderkors og dannebrogsmændenes hæderstegn (sølvkorset). Heraf gik godt 300 ridderkors til officersgruppen, mens knap 1.700 menige og underbefalingsmænd modtog sølvkorset som belønning for deres indsats. Denne fordeling afspejlede så nogenlunde styrkeforholdet mellem officerer og øvrige grupper i den daværende hærstyrke.

Under og lige efter 2. Slesvigske Krig i 1864 uddeltes der blot i alt 750 dekorationer for tapper krigsdeltagelse. Det lave tal må formentlig tages som udtryk for, at det officielle Danmark ikke fandt, at der var noget at fejre efter det knusende nederlag, som man helst så fortone sig i glemslens tåger. Det forholdt sig yderligere sådan, at næsten 
halvdelen - helt præcist 320 - af disse 750 dekorationer var ridderkors, der gik til officersgruppen. Det svarede til, at næsten 24 procent af de deltagende officerer modtog en dekoration for deres indsats. De resterende 430 dekorationer var sølvkors til menige og underbefalingsmænd. Denne mandskabsgruppe omfattede imidlertid ikke færre end 71.000 mand, hvorfor realiteten var, at kun omkring en halv procent af de menige og underbefalingsmændene modtog en officiel ordensmæssig anerkendelse for deres indsats i krigen. Der var med andre ord tale om en iøjnefaldende og ganske uretfærdig skævhed i ordenstildelingerne, hvilket som nævnt sikkert må sættes i forbindelse med nederlagets traumatiserende virkning på landets ledelse fra kongen og nedefter. Det var dette skæve regnskab, som Christian $X$ gerne ville rette op på, da lejligheden bød sig efter Genforeningen, efter devisen bedre sent end aldrig.

På hans initiativ blev der i den følgende tid gennem soldaterforeninger, veteransammenslutninger og lignende iværksat et omfattende opsøgende arbejde for at opspore endnu levende fortjente veteraner fra 1864-krigen og tildele dem det sølvkors, som de så ærligt havde fortjent, men af forskellige grunde aldrig fået. Det var ikke et øjeblik for tidligt, eftersom de på dette tidspunkt typisk havde rundet de 80 år. Ikke desto mindre lykkedes det i løbet af 1920'erne at opspore et ganske betragteligt antal veteraner både nord og syd for den tidligere kongeågrænse og tildele ikke færre end 2.000 gamle mænd det sølvkors, som de omkring 60 år tidligere havde gjort sig fortjente til. Resultatet af dette kongelige initiativ rettede i sidste øjeblik lidt op på den oprindelige skævhed $\mathrm{i}$ tildelingen af ridderkors og sølvkors. Og samtidig var dette dekorationsinitiativ et klart signal fra kongen om, at det samlede regnskab for 1864-krigen nu var gjort op både $\mathrm{i}$ forhold til befolkningen og $\mathrm{i}$ forhold til Tyskland. Den kongelige dekorationspolitik i forbindelse med Genforeningen sendte samlet set det budskab, at tiden nu var inde til endegyldigt at lukke det kapitel i danmarkshistorien, som i en menneskealder havde redet den danske befolkning som en mare.

Det var - og er - skik, at modtagerne af en kongelig orden i forbindelse med dekorationen indsender en skriftlig selvbiografi - et levnedsløb - til kongens ordenskapitel, hvor den indgår i en righoldig og stadig voksende personalhistorisk samling. Denne skik blev troligt efterlevet af de mange sønderjyder og veteraner, der blev dekoreret $i$ forbindelse med Genforeningen. Deres beretninger om usædvanlige 


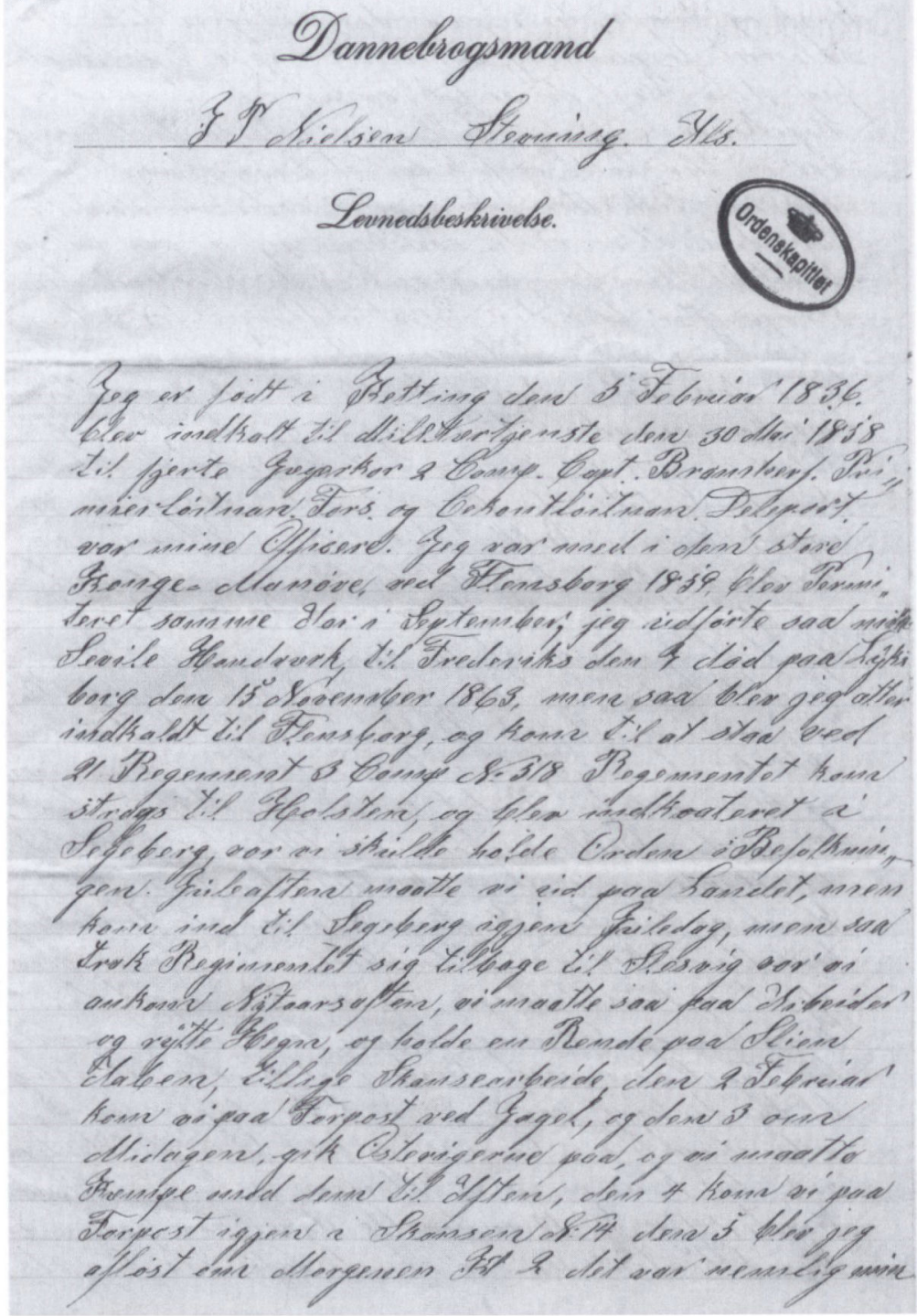

Eksempel på en levnedsbeskrivelse indleveret til Ordenskapitlet af en veteran fra 1864. Denne er usædvanlig kort. Typisk fylder veteranberetningerne 3-4 håndskreone sider. Fra Vejen hjem, s. 142. 
og ofte nøjsomme livsforløb udgør den dag i dag et væsentligt element $\mathrm{i}$ denne kongelige samling. ${ }^{18}$ De vidner i kraft af deres indhold og mængde om, at det ikke blot var Christian X, der som foran beskrevet følte et særligt tilhørsforhold til Sønderjylland, men at sønderjyderne omvendt også udviklede et nøje troskabsforhold til kongen så nøje, at han stadig i landsdelen kærligt-fortroligt ofte omtales som »Kette Kryds«. Sønderjylland spillede som vist en determinerende rolle i Christian X's tidlige kongegerning. Til gengæld blev kongen i Sønderjylland selve indbegrebet af danskhed. De to - kongen og Sønderjylland - blev på næsten mystisk vis sammenknyttet i et skæbnefællesskab, der har sat sit dybe præg på den nyere danmarkshistorie.

\section{KILDER OG LITTERATUR}

\section{Kilder}

Det primære kildemateriale, der ligger til grund for artiklen, er Christian $X$ 's omfattende dagbogsmateriale i kongehusarkivet i Rigsarkivet samt Ordenskapitlets Arkiv. Til denne artikel er der imidlertid udelukkende anvendt kildestof, der allerede foreligger aftrykt i Rytterkongen (2007) og Vejen hjem (2012).

\section{Litteratur}

Adriansen, Inge m.fl. (red.): Sonderjylland $A-A$, Aabenraa 2011.
Buk-Swienty, Tom: Dommedag Als 29. juni 1864, København 2010.

Jespersen, Knud J.V.: Rytterkongen. Et portræet af Christian 10., København 2007.

Jespersen, Knud J.V.: Vejen hjem. Sønderjyske skabner 1864-1920, København 2012.

Rud, Helene: Jomfru Fanny, København 1945.

Stevnsborg, Lars: Kongeriget Danmarks ordener, medaljer og hæderstegn, Odense 2005.

\section{NOTER}

1. Rytterkongen, s. 292, citeret efter Christian X's politiske dagbog under 10.2. 1920.

2. Den følgende redegørelse for kongens holdninger og optræeden i genforeningssagen bygger $i$ hovedsagen på afsnittet om Påskekrisen i Rytterkongen, s. 276-322, hvor også de anførte citater fra kongens dagbogsoptegnelser er trykt.

3. Dommedag Als, s. $351 \mathrm{ff}$.

4. Rytterkongen, s. 287, citeret efter Christian X's private dagbog 31.12. 1918.
5. Samtalen med Scavenius refereres $i$ kongens politiske dagbog under 18.10.1918; Rytterkongen, s. 287.

6. Citat fra kongens politiske dagbog 6.11.1918; Rytterkongen, s. 287. Med bemærkningen om islændingene sigtede kongen til Forbundsloven af 1918, der gjorde Island til et selvstændigt kongerige $i$ personalunion med Danmark, det vil sige med Christian X som det fælles statsoverhoved. Loven stadfæstedes endeligt den 30.11.1918.

7. Samtalen med Edvard Brandes refe- 
reres i kongens politiske dagbog under 14.5.1919; Rytterkongen, s. 288.

8. Udtalelsen er optegnet $\mathrm{i}$ kongens politiske dagbog under 30.6.1919; Rytterkongen, s. 290.

9. Christian X's samtale med Svenn Poulsen refereres i kongens politiske dagbog under 27.10.1919; Rytterkongen, s. 290.

10. Kongens eget referat af samtalen med Scavenius i hans politiske dagbog under 11.1.1920; Rytterkongen, s. 290.

11. Ordvekslingen på mødet er refereret $i$ kongens politiske dagbog under 10.3.1920; Rytterkongen, s. 29293.
12. Indførsel $\mathrm{i}$ kongens private dagbog 31.12.1920; Rytterkongen, s. 311.

13. Jomfru Fannys spådom gengives i Jomfru Fanny, s. 31.

14. Kongens private dagbog under 11.7.1920; Rytterkongen, s. 23.

15. Vejen Hjem, s. 57.

16. Sst., s. 53-54. De anforte tal er hentet i opslagsværket Sønderjylland $A-\AA$.

17. Afsnittet om ordensvasenet og sønderjyderne bygger på Vejen hjem, s. 59 ff., og oplysninger fra Kongeriget Danmarks ordener, medaljer og hxderstegn.

18. En mindre del af disse (60 stk.) er $i$ let redigeret form udgivet $i$ Vejen hjem.

\section{Zusammenfassung}

Die Frage der Wiedervereinigung, die nach dem Zusammenbruch Deutschlands aktuell wurde, brachten Christian $X$ und die radikale Regierung unter Leitung von C. Th. Zahle auf direkten Kollisionskurs. Die Regierung vertrat den Standpunkt, dass die neue Grenze zwischen Dänemark und Deutschland auf dem Nationalitätsprinzip bauen solle, um zukünftige Konflikte mit Deutschland zu vermeiden. Christian $X$ wollte aber die Grenze südlicher verlegen lassen. Es kam zur hochgespannten Påskekrise (Osterkrise) im März 1920, die zum Rücktritt der Regierung und nahezu revolutionären Zuständen führte, bis sich die Verhältnisse wieder beruhigten.

Im Artikel werden auf Grund eigener Aussagen von Christian $X$ Argumente dafür angeführt, dass die dreiste Handlungsweise vom Verhalten zur Idee des Gesamtstaates herrührte, ein Erbe von seinem Großvater, Christian IX, und von dem brennenden Wunsch, den Flecken an der Ehre der Königsfamilie zu entfernen, den der Verlust der Herzogtümer 1864 hinterlassen hatte.

Die Grenze wurde nach den Nationalitätsprinzipien festgelegt und es kam zur Niederlage der Gedanken vom Gesamtstaat von Christian $X$. Die Wiedervereinigungsbestrebungen gaben dem König die einzigartige Gelegenheit, aus dem politisierenden Monarchen einen unanfechtbaren nationalen Sammlungspunkt zu machen. Nordschleswig spielte so eine entscheidende Rolle in der Entwicklung der dänischen 
Monarchie, der König erreichte im wiedergewonnen Teil des Landes sehr große Beliebtheit, im Volksmund nannte man ihn liebevoll »Kette Kryds« (Kette Kreuz). 